\title{
KONSERVASI TANAH DAN KARBON MELALUI PEMANFAATAN BIOCHAR PADA PERTANAMAN KEDELAI
}

\author{
Endriani dan Agus Kurniawan \\ Staf pengajar Jurusan Agroekoteknologi Fakultas Pertanian Universitas Jambi \\ Kampus Pinang Masak, Mendalo - Indah Jambi 36361 \\ email: Eend_200662@yahoo.co.id; aguskurniawan_iwan@gmail.com
}

\begin{abstract}
ABSTRAK
Perbaikan kualitas lahan kering terdegradasi merupakan keharusan, khususnya untuk menunjang ketahanan pangan. Bahan pembenah tanah berupa biochar merupakan salah satu alternatif yang dapat digunakan untuk memulihkan lahan - lahan kering terdegradasi. Tujuan penelitian ini adalah: 1. Mempelajari pengaruh beberapa formula arang hayati terhadap konservasi tanah dan karbon melalui pemanfaatan biochar pada pertanaman kedelai. Penelitian lapangan dilaksanakan pada lahan petani order Utisol di Desa Talang Kerinci Kecamatan Sungai Gelam Kabupaten Muaro Jambi, sedangkan analisis tanah akan dilakukan di Laboratorium Fisika dan Mineralogi Tanah dan Laboratorium Kimia dan Kesuburan Tanah Fakultas Pertanian UNJA. Penelitian akan dilakukan selama 6 bulan pada tahun 2017. Penelitian dirancang menggunakan rancangan acak kelompok (RAK) dengan perlakuan introduksi soil amandement sebagai berikut : b0 : kontrol; b1 : biochar sekam padi 5 ton/ha ; b2:biochar serbuk gergaji 5 ton/ha; b3 : biochar tempurung kelapa 5 ton/ha ; b4 : biochar sekam padi 10 ton/ha; b5: biochar serbuk gergaji 10 ton/ha; b6 : biochar tempurung kelapa 10 ton/ha. Semua peubah kualitas tanah dan komponen agronomis tanaman kedelai serta komponen produksi dianalisis secara statistik dan dilakukan uji lanjut Duncan Mutiple Range Test (DNMRT) pada taraf a $5 \%$. Hasil penelitian menunjukkan bahwa : (1) Pemberian biochar sekam padi, biochar serbuk gergaji dan biochar tempurung kelapa sudah dapat meningkat kandungan bahan organik, menurunkan bobot volume dan meningkatkan porositas total; (2) pemberian biochar sekam padi, biochar serbuk gergaji dan tempurung kelapa meningkatkan biomassa pucuk dan biomassa perakaran tanaman, serta meningkatkan biomassa total; (3) Pemberian biochar sekam padi, serbuk gergaji dan tempurung kelapa menghasilkan cadangan karbon tanah tertinggi; (4) Sekuestrasi karbon tertinggi terjadi pada lahan, dimana cadangan karbon tanaman tertinggi adalah pada bagian puucuk tanaman ; (5) Pemberian biochar sekam padi, serbuk gergaji dan tempurung kelapa meningkatkan bobot kering biji kedelai. Hasil kedelai tertinggi dijumpai pada pertanaman uyang diberi biochar sekam padi 10 ton/ha.
\end{abstract}

Kata Kunci: Arang Hayati, Kualitas Tanah, Hasil Kedelai, Lahan Kering Terdegradasi

\section{PENDAHULUAN}

Konservasi tanah adalah usaha meningkatkan dan memelihara kualitas tanah dari kemerosotan akibat erosi air dan angin serta pengurasan hara dan bahan organik yang berlebihan (Agus dan Widianto, 2004). Menghangatnya isu pemanasan global dan perubahan iklim dewasa ini menyebabkan peran konservasi tanah menjadi makin penting karena dapat berkontribusi dalam mengatasi dampak perubahan iklim melalui upaya mitigasi dan adaptasi.Konservasi tanah tidak hanya dapat mempertahankan dan meningkatkan 
produktivitas tanah, tetapi juga cadangan karbon (carbon stock), baik di dalam maupun di atas permukaan tanah.

Karbon organik pada tanah mineral berperan penting dalam menurunkan kepadatan tanah, memperbaiki aerasi tanah, membentuk dan menstabilkan agregat tanah, meningkatkan permeabilitas dan kemampuan tanah memegang air, menjaga kelembapan dan suhu tanah, menurunkan energi kinetik air hujan, meningkatkan infiltrasi, dan mengurangi aliran permukaan dan erosi (Agus et al., 2011). Bahan organik memperbaiki sifat kimia tanah dengan menurunkan $\mathrm{pH}$ tanah alkalin, mengikat logam beracun dengan membentuk kompleks kelat, dan meningkatkan kapasitas tukar kation dan ketersediaan hara bagi tanaman. Bahan organik juga merupakan sumber energi bagi aktivitas mikroba dan fauna tanah.

Peran konservasi karbon pada tanah mineral adalah untuk menjaga kandungan $\mathrm{C}$ organik tanah pada tingkat yang relatif tinggi, 2-8\%. Kisaran ini penting untuk menjaga kesuburan tanah dan keberlanjutan (sustainability) usaha pertanian. Tanah yang miskin bahan organik umumnya telah mengalami degradasi, dan rehabilitasinya selalu dimulai dengan konservasi tanah dan karbon untuk mitigasi perubahan iklim ( Agus, 2011) pemulihan kandungan bahan organik atau $\mathrm{C}$ organik tanah.

Usaha pertanian yang intensif dan perubahan penggunaan lahan menyumbang $15-20 \%$ dari total emisi global, sekitar 29,9 Gt CO2 -e/tahun (Cline 2007). Indonesia menyumbang sekitar $1,8 \mathrm{Gt} \mathrm{CO} 2$-e pada tahun 2005 dan menjelang tahun 2020 emisi GRK tahunan diperkirakan mendekati 3 Gt CO2 -e. Lebih dari 60\% emisi nasional tersebut bersumber dari perubahan penggunaan lahan dan lahan gambut (Kementerian Lingkungan Hidup 2009). Hal ini mununjukkan opsi mitigasi di bidang penggunaan lahan dan lahan gambut memegang peranan penting dalam mengatasi emisi GRK.

Terkurasnya karbon di dalam dan di atas permukaan tanah merupakan indikasi terdegradasinya lahan. Penurunan cadangan karbon memengaruhi kesuburan tanah. Tingginya cadangan karbon (sampai tingkat tertentu) di dalam tanah dan tanaman merupakan cerminan kesuburan dan produktivitas tanah. Tanah dengan kandungan karbon relatif tinggi, selain mampu menopang pertumbuhan dan produksi tanaman secara memuaskan, juga dapat menjaga kelestarian dan keasrian lingkungan serta keseimbangan tata air daerah aliran sungai dan ekosistem di sekitarnya. Apabila karbon yang tersimpan pada tanah dan tanaman diemisikan secara berlebihan, maka akan terjadi percepatan erosi, degradasi lahan, dan ketidakseimbangan ekosistem (Agus dan Widianto 2004; Agus, 2010). Karbon di dalam tanah berada dalam bentuk senyawa organik dan sebagian kecil dalam bentuk karbonat (Agus et al. 2011). Karbon organik mudah terdekomposisi oleh mikroba tanah menghasilkan $\mathrm{CH} 4$ dan $\mathrm{CO} 2$. Di atmosfer, CO2 yang berasal dari dekomposisi bahan organik tanah dan tanaman bergabung dengan $\mathrm{CO} 2$ dari sumber lainnya (kendaraan, pabrik) dan dengan GRK lainnya seperti CH4 dan N2 O (IPCC 2007a). Sebagian gas CO2 diserap kembali oleh tanaman melalui proses fotosintesis membentuk karbohidrat dan jaringan tanaman. Tanaman menggugurkan daun, ranting, dan dahan membentuk nekromas (jaringan tanaman yang mati). Sebagian nekromas terkonservasi dalam bentuk karbon organik tanah, sedangkan sebagian lainnya terdekomposisi menghasilkan CO2 (Agus dan Widianto 2004).

Cadangan karbon merupakan jumlah karbon yang tersimpan di dalam berbagai tempat penyimpan (pool). Pool yang terpenting adalah tanah, biomassa tanaman, dan jaringan 
tanaman yang mati (nekromas) (Agus, 2011; Hairiah, 2011). Tanah dan tanaman mempunyai cadangan karbon yang bervariasi. Cadangan karbon di dalam tanah gambut berkisar antara 300-800 t C/ha untuk setiap meter ketebalan gambut. Pada gambut dengan ketebalan $0,5 \mathrm{~m}$ sampai lebih dari $8 \mathrm{~m}$, cadangan karbon berkisar antara $200 \mathrm{t}$ sampai lebih dari $6.400 \mathrm{t} \mathrm{C} / \mathrm{ha}$ (Agus 2007; Agus dan Subiksa 2008; Agus, 2010, 2011, 2012). Pada tanah mineral, C organik umumnya terkonsentrasi pada lapisan 0-100 cm (IPCC, 2006). Cadangan karbon tanah mineral berkisar antara 15-200 t C/ha, namun adakalanya dari $1 \mathrm{t}$ sampai $900 \mathrm{t} \mathrm{C} / \mathrm{ha}$ (Shofiyati, 2010).

Seperti halnya di dalam tanah, cadangan karbon di jaringan biomassa tanaman bervariasi, bergantung pada tingkat kesuburan tanah, iklim, elevasi, jenis dan tingkat pertumbuhan tanaman, tipe penggunaan lahan, dan sistem pengelolaan. Hutan mempunyai cadangan karbon 150-200 t C/ha. Perkebunan kelapa sawit mempunyai cadangan karbon rata-rata $40 \mathrm{t} \mathrm{C/ha,}$ mendekati nol sebelum ditanam dan sekitar $80 \mathrm{t}$ C/ha setelah tanaman berumur 15-25 tahun (van Noordwijk, 2010). Tanaman karet memiliki cadangan karbon rata-rata 40-80 t C/ha. Lahan terdegradasi yang ditumbuhi semak dan belukar mempunyai cadangan karbon 15-30 t $\mathrm{C} /$ ha (Istomo, 2006). Lahan terdegradasi yang ditumbuhi paku resam, rumput, dan padang alang-alang memiliki cadangan karbon yang lebih rendah, berkisar 2-10 t C/ha, hampir sama dengan lahan yang diusahakan dengan tanaman semusim ( Brearly, 2004; Palm, 2004; Rahayu, 2005; Hairiah dan Rahayu 2007).

Menurut Masulili, (2014) pada tanah yang diberi arang sekam padi 5 ton $\mathrm{ha}^{-1}$, total pori tanah mengalami peningkatan dari $44.43 \%$ menjadi $54.21 \%$. Total pori tanah pada pemberian arang sekam padi 5 ton $\mathrm{ha}^{-1}$ bersama biomasa Cromolaena odorata 10 ton ha $\mathrm{ha}^{-1}$ meningkat menjadi $56.73 \%$ dan merupakan pori total tertinggi berbeda nyata dengan perlakuan lainnya. Sedangkan pada pemberian biochar sekam padi 5 ton ha $^{-1}$ bersama jerami padi 10 ton $\mathrm{ha}^{-1}$, pori total tanah menjadi $55.57 \%$. Kondisi ini membuktikan bahwa arang sekam padi memiliki kontribusi yang lebih baik terhadap peningkatan porositas tanah dibanding abu sekam (total pori $47.30 \%$ ).

Pemberian biochar dan kompos selain berpengaruh ke tanah juga berpengaruh terhadap tanaman. Hasil penelitian Rona, (2014) menunjukkan bahwa pemberian biochar (sekam dan tempurung) dengan dosis 2,5 ton ha ${ }^{-1}$ dan kompos 12,5 ton $\mathrm{ha}^{-1}$ cenderung menghasilkan tinggi tanaman cabai yang lebih baik dari perlakuan lainnya, sedangkan untuk dosis terbaik terhadap jumlah buah adalah kombinasi kompos dosis tinggi 12,5 ton ha ${ }^{-1}$ dengan biochar dosis rendah 2,5 ton ha ${ }^{-1}$ dan untuk hasil panen dan bobot kering perlakuan terbaik adalah pada pemberian kompos dengan biochar tempurung.

Menurut Endriani et al., (2013) pemberian biochar cangkang kelapa sawit mempengaruhi pertumbuhan tinggi tanaman setelah 8 minggu setelah tanam (MST). Semakin tinggi takaran biochar yang diaplikasikan ke dalam tanah menyebabkan pertumbuhan tanaman semakin baik pula. Pada pemberian biochar dengan dosis 2 ton ha-1 dapat meningkatkan pertumbuhan tanaman, biomassa tanaman dan hasil tanaman kedelai. Menurut Sukartono, (2012) tanaman jagung menunjukkan respon positif terhadap aplikasi biochar, hasil biji jagung rata-rata dalam tiga siklus musim tanam dengan takaran 15 ton ha ${ }^{-1}$ mencapai 5,54 ton/ha dan 5,51 ton ha $\mathrm{ha}^{-1}$ untuk perlakuan biochar tempurung kelapa dan biochar kotoran sapi, sedangkan pupuk kandang aplikasi setiap musim tanam 5,62 ton $\mathrm{ha}^{-1}$ aplikasi tunggal pupuk kandang 5,36 ton 
$\mathrm{ha}^{-1}$ dan kontrol mencapai 4,83 ton $\mathrm{ha}^{-1}$. Menurut Sudjana (2014) biochar sekam padi yang mengandung unsur silika telah memberikan berat biomassa tanaman jagung tertinggi yaitu 245,44 gram dan serapan $\mathrm{N}$ di daun tertinggi yaitu 13,57 mg pada setiap tanaman.

Secara umum tujuan penelitian ini adalah untuk mempelajari dan mengetahui pengaruh beberapa jenis biochar terhadap konservasi tanah dan karbon serta pengaruhnya terhadap hasil kedelai.

\section{METODE PENELITIAN}

\section{Tempat dan Waktu}

Penelitian ini dilaksanakan di Desa Talang Kerinci, Kecamatan Sungai Gelam, Kabupaten Muaro Jambi. Untuk analisis tanah dilakukan di Laboratorium Fisika Tanah Fakultas Pertanian Universitas Jambi dan Laboratorium Kimia, Biologi dan Kesuburan Tanah Fakultas Pertanian Universitas Sriwijaya. Penelitian dimulai dari bulan Juni sampai bulan Agustus 2017.

\section{Rancangan Penelitian}

Penelitian ini berupa percobaan (eksperimen) dengan menggunakan Rancangan Acak Kelompok (RAK) dengan 7 perlakuan dan 4 kelompok, sehingga terdapat 28 petak percobaan. Ukuran petak percobaan $3 \mathrm{~m}$ x $2 \mathrm{~m}$ dengan jarak tanam $20 \mathrm{~cm}$ × $30 \mathrm{~cm}$ sehingga jumlah tanaman dalam satu petak yaitu 100 tanaman.

Adapun perlakuan yang digunakan dalam penelitian adalah :

$\mathrm{b}_{0} \quad=$ Tanpa pemberian biochar dan kompos (kontrol)

$\mathrm{b}_{1} \quad=$ Biochar sekam padi $\left(5\right.$ ton $\left.\mathrm{ha}^{-1}\right)$

$\mathrm{b}_{2} \quad=$ Biochar serbuk gergaji $\left(5\right.$ ton $\left.\mathrm{ha}^{-1}\right)$

$\mathrm{b}_{3} \quad=$ Biochar tempurung kelapa $\left(5\right.$ ton $\mathrm{ha}^{-1}$

$\mathrm{b}_{4} \quad=$ Biochar sekam padi $\left(10\right.$ ton $\left.\mathrm{ha}^{-1}\right)$

$\mathrm{b}_{5} \quad=$ Biochar serbuk gergaji $\left(10\right.$ ton $\left.\mathrm{ha}^{-1}\right)$

$\mathrm{b}_{6} \quad=$ Biochar tempurung kelapa $\left(10\right.$ ton $\left.\mathrm{ha}^{-1}\right)$

\section{Persiapan lahan}

Lahan yang digunakan dibersihkan terlebih dahulu, setelah itu diukur sesuai dengan kebutuhan. Lahan diolah dengan menggunakan cangkul dengan kedalaman $20 \mathrm{~cm}$, digaru sampai gembur dan diratakan. Kemudian dibuat petak-petak percobaan dengan panjang $3 \mathrm{~m}$ dan lebar $2 \mathrm{~m}$ sebanyak 28 petakan. Jarak antar kelompok $1 \mathrm{~m}$ dan antar perlakuan $0,5 \mathrm{~m}$

\section{Pemberian perlakuan}

Setelah pembuatan petakan selesai dilakukan pemberian biochar dengan dosis 2,5 ton ha-1 sebanyak 1,5 kg/petak, 5 ton ha ${ }^{-1}$ sebanyak $3 \mathrm{~kg} /$ petak dan kompos 5 ton ha ${ }^{-1}$ sebanyak 4,8 $\mathrm{kg} /$ petak. Dapat dilihat pada (lampiran 4). Biochar dan kompos diberikan sesuai dengan perlakuan. Biochar dan kompos disebar merata di permukaan tanah pada masing-masing petakan, kemudian dicampur dengan tanah sedalam $\pm 20 \mathrm{~cm}$ dengan cara pencangkulan dan di inkubasi selama 1 minggu..

\section{Penanaman dan Pemberian Pupuk Kimia}

Penanaman dilakukan 1 minggu setelah pemberian biochar dan kompos. Sebelum ditanam benih kedelai diberi inokulum rhizobium. Penanaman benih kedelai dilakukan dengan cara 
tugal pada kedalaman $\pm 3 \mathrm{~cm}$ sebanyak 2 benih perlubang tanam dengan jarak tanam $20 \mathrm{~cm} \mathrm{x}$ $30 \mathrm{~cm}$, denah tata letak tanaman dalam petak percobaan dapat dilihat pada (lampiran 5). Benih yang ditugal ditambahkan dengan Furadan secukupnya dan selanjutnya tutup dengan tanah yang gembur.

Pupuk kimia yang digunakan berupa pupuk Urea dengan dosis $50 \mathrm{~kg} \mathrm{ha}^{-1}$, TSP dengan dosis $100 \mathrm{~kg} \mathrm{ha}^{-1}$, dan $\mathrm{KCl}$ dengan dosis $100 \mathrm{~kg} \mathrm{ha}^{-1}$. Pemberian pupuk dilakukan pada saat tanam secara larikan dengan jarak dan kedalaman $5 \mathrm{~cm}$ dari lubang tanam. Perhitungan dosis pupuk anorganik dapat dilihat pada (lampiran 6).

\section{Pemeliharaan}

Pemeliharaan tanaman meliputi penyiraman, penyulaman, penjarangan serta pengendalian hama dan penyakit. Penyiraman dilakukan tergantung kondisi di lapangan (apabila turun hujan tidak dilakukan penyiraman, jika tidak turun hujan penyiraman dilakukan pagi dan sore hari). Penjarangan dilakukan dengan maksud memilih dan memelihara satu tanaman terbaik dari dua tanaman yang tumbuh dalam satu lubang. Penjarangan dilakukan setelah tanaman berumur dua minggu. Penyulaman dilakukan bersamaan dengan penjarangan untuk mengganti tanaman yang tumbuhnya tidak normal ataupun mati. Penyiangan dilakukan $2-3$ hari selama masa pertumbuhan atau sesuai kondisi keberadaan gulma pada petak percobaan. Pengendalian hama dan penyakit dilakukan secara preventif sebelum gejala serangan hama dan penyakit muncul pada tanaman. Penyemprotan dilakukan secara berselang seling 1 minggu dengan Decis dan Dithane M-45.

\section{Peubah yang Diamati}

Peubah yang diamati dan analisis tanah meliputi Tanah dan tanaman. Pengambilan sampel tanah akhir diambil pada saat setelah panen. Adapun parameter tanah yang diamati diantaranya : Kandungan Bahan Organik; Kandungan bahan organik tanah ditetapkan berdasarkan kandungan C-organik tanah dengan menggunakan sampel tanah komposit yang telah diovenkan pada suhu $105^{\circ} \mathrm{C}$ selama 1 x 24 jam. C-organik dianalisis dengan menggunakan Metode Pengabuan Kering/furnace pada suhu $375^{\circ} \mathrm{C}$ selama 3,5 jam. Kandungan bahan organik dihitung menggunakan rumus:

$$
B O(\%)=\% C-\operatorname{org} x 1,724
$$

\section{Bobot volume tanah (BV).}

Penetapan bobot volume tanah di laboratorium dengan Metode Gravimetri menggunakan sampel tanah utuh dalam ring sampel yang dioven dengan suhu $105^{\circ} \mathrm{C}$ selama 2 x 24 jam.

$$
B V=\frac{\text { Berat Tanah Kering }(\mathrm{gr})}{\text { Volume Tanah }(\mathrm{cm} 3)}
$$

Ket : $\quad \mathrm{BV}=$ Bobot Volume Tanah $\left(\mathrm{gr} \mathrm{cm}^{-3}\right)$

\section{Total ruang pori tanah}

Perhitungan total ruang pori tanah diperoleh dengan menggunakan rumus sebagai berikut:

$$
T R P=\left(1-\frac{B V}{B J-(0,02 \times \% B O)}\right) \times 100 \% \rightarrow \text { bila } B O>1 \%
$$




\section{Biomassa tanaman.}

Biomassa tanaman ditentukan dengan menimbang biomassa dari tanaman pada setiap unit percobaan yang diperoleh secara destruktif. Sampel ditimbang berat basahnya, kemudian dikering oven pada suhu $60{ }^{\circ} \mathrm{C}$, selanjutnya ditimbang berat kering biomassa.

Karbon tanaman. Kandungan karbon tanaman diukur dengan metode pengabuan kering. Karbon diukur pada bagian akar, daun dan batang.

$$
C=\text { Biomassa } \times \% \text {-bagian tanaman }
$$

Total Karbon Sekuestrasi. Total karbon sekuestrasi ditentukan dengan rumus :

$\mathrm{C}$ sekuestrasi $=\mathrm{C}_{\mathrm{akar}}+\mathrm{C}_{\text {daun }}+\mathrm{C}_{\text {batang }}$

Cadangan Karbon Tanah. Cadangan karbon tanah ditentukan berdasarkan Bobot volume tanah dan $\% \mathrm{C}$ organic tana.

$\mathrm{CK}_{\text {tanah }}=\mathrm{V}_{\operatorname{tanah}} \mathrm{x} \mathrm{BV} \times \mathrm{x}$ C-organik tanah (ton/ha)

\section{Hasil Tanaman}

Hasil panen kedelai meliputi bobot kering per petak. Pengamatan terhadap produksi dihitung dari hasil tanaman (berat bobot kering) per petak ubinan. Hasil panen kedelai dikonversi menjadi $\mathrm{kg}_{\text {petak }}{ }^{-1}$.

\section{Analisis Data}

Data yang diperoleh kecuali data pertumbuhan tanaman dalam penelitian ini di analisis ragam pada taraf $5 \%(\alpha=0,05)$ untuk melihat pengaruh rata - rata perlakuan dilanjutkan dengan menggunakan uji Duncan. Pertumbuhan tanaman kedelai di analisis secara deskriptif berdasarkan grafik laju pertumbuhan yang diamati.

\section{HASIL DAN PEMBAHASAN}

\section{Sifat Fisik Tanah dan Cadangan Arbon Tanah}

Hasil penelitian menunjukkan bahwa aplikasi beberap jenis bahan biochar berpengaruh terhadap kandungan bahan organic tanah, yang mengalami peningkatan dibandingkan dengan tanpa perlakuan (Tabel 1). Pemberian biochar sekam padi 10 ton/ha mengalibatkan tingginya kandungan bahan organik tanah, diikuti biochar tempurung kelapa dan biochar serbuk gergaji kayu. Hal ini sesuai dengan yang ditemukan peneliti sebelumnya bahwa biochar adalah sumber karbon yang dapat bertahan lama dalam tanah Doan et al., (2015), Carvalho et al., (2014) dan Githinji (2013), IBI (2012); Sukartono et al., (2012) serta Nurida et al., (2012) . Berbagai jenis bahan biochar yang ditambahkan ke dalam tanah mempengaruhi kandungan bahan organik di dalam tanah, yang umumnya terjadi peningkatan C-organik di dalam tanah.

Tabel 1. Pengaruh Aplikasi Biochar Terhadap Kandungan Bahan Organik Tanah, Bobot Volume, Total Ruang Pori, Serta Cadangan Karbon Tanah

\begin{tabular}{lcccccccc}
\hline \multicolumn{1}{c}{ Perlakuan } & \multicolumn{2}{c}{ SOC (\%) } & \multicolumn{2}{c}{ BV $(\mathrm{g} / \mathrm{cm})$} & \multicolumn{2}{c}{ TRP $(\%)$} & \multicolumn{2}{c}{$\begin{array}{c}\text { Cad karbon Tanah } \\
\text { (ton/ha) }\end{array}$} \\
\hline Kontrol & 1.57 & $\mathrm{f}$ & 1.38 & $\mathrm{a}$ & 50.67 & $\mathrm{c}$ & 217.31 & $\mathrm{e}$ \\
BSP 5 ton/ha & 2.22 & $\mathrm{~cd}$ & 1.23 & $\mathrm{c}$ & 55.68 & $\mathrm{ab}$ & 273.31 & $\mathrm{~cd}$ \\
BSG 5 ton/ha & 2.01 & de & 1.28 & $\mathrm{~b}$ & 52.60 & $\mathrm{bc}$ & 256.65 & $\mathrm{de}$ \\
BTK 5 ton/ha & 1.82 & ef & 1.28 & $\mathrm{~b}$ & 52.98 & $\mathrm{bc}$ & 231.76 & $\mathrm{de}$ \\
& & & & & & & & \\
\hline \hline
\end{tabular}




\begin{tabular}{llclcllll}
\hline \hline BSP 10 ton/ha & 3.14 & $\mathrm{a}$ & 1.18 & $\mathrm{e}$ & 57.07 & $\mathrm{a}$ & 370.34 & $\mathrm{a}$ \\
BSG 10 ton/ha & 2.61 & $\mathrm{bc}$ & 1.22 & $\mathrm{~cd}$ & 53.36 & $\mathrm{~b}$ & 319.28 & $\mathrm{bc}$ \\
BTK 10 ton/ha & 2.92 & $\mathrm{ab}$ & 1.21 & $\mathrm{~d}$ & 53.98 & $\mathrm{~b}$ & 355.24 & $\mathrm{ab}$ \\
\hline
\end{tabular}

Keterangan: Angka-angka yang diikuti huruf kecil yang sama pada kolom yang sama berbeda tidak nyata menurut uji Duncan pada taral alpha $5 \%$

Beberapa strategi yang mungkin dapat dilakukan untuk mempercepat sekuestrasi karbon organik tanah, antara lain: meningkatkan pertumbuhan biomassa akar dan mengelola distribusi akar vertikal; memilih tanaman dan jenis tanaman dengan biomassa di bawah tanah (akar) yang mempunyai kadar yang lebih tinggi dalam senyawa tahan terhadap proses biokimiawi (biochemical recalcitrant compounds), yaitu senyawa lignin, tannin, cutan, dan suberan (Lorenz, 2005); ketersediaan kadar air yang memadai dan pasokan nutrisi untuk pertumbuhan akar untuk meningkatkan akumulasi karbon organik yang dapat berkelanjutan di dalam tanah dengan produksi residu akar yang tinggi.nKonsentrasi karbon organik tanah tergantung pada produktivitas biomassa dan intensitas mineralisasi bahan organik, yang secara kuat dikontrol oleh kondisi hidrotermal dan tekstur tanah. Hampir semua karbon organik dalam tanah terletak di dalam pori-pori antara partikel mineral, baik sebagai partikel diskrit/individual ataupun sebagai molekul teradsorpsi ke permukaan partikel-partikel mineral liat tanah. Bangunan tanah dapat mempengaruhi stabilitas biologis bahan organik melalui efeknya pada ketersediaan air dan oksigen, jebakan (entrapment) dan isolasi dari dekomposer, dan melalui dinamika agregasi tanah. Bobot volume tanah menjadi semakin rendah akibat pemberian biochar, pemberian biochar 5 ton/ha sudah dapat menurunkan kepadatan tanah. Namun semakin tinggi takaran biochar yang diberikan semakin rendah juga bobot volume tanah. Hal ini disebabkan biochar yang bersifat sangat sarang dan ringan seperti spon sehingga jika diberikan ke dalam tanah juga akan menurunkan kepadatan tanah. Hasil penelitian ini mendukung penelitian sebelumnya Sika (2012); IBI (2012); bahwa pemberian biochar ke dalam tanah mengurangi kepadatan tanah. Hasil penelitian menunjukkan bahwa porositas tanah semakin meningkat akibat pemberian biochar, sejalan dengan penjelasan sebelumnya biochar menurunkan kepadatan tanah yang berarti meningkatkan porositas tanah. Biochar yang bersifat sarang jika dicampur ke dalam tanah juga menyebabkan tanah semakin sarang dan gembur. Hasil penelitian ini sesuai dengan yang ditemukan peneliti peneliti sebelumnya Doan, (2015), Carvalho, (2014) dan Githinji (2013), IBI (2012); Sukartono, (2012) ; Nurida, (2012) serta Masulili, (2010) bahwa biochar dari berbagai bahan dan suhu pembuatan yang beragam yang jika diberikan ke dalam tanah meningkatkan porositas tanah.

Menurunnya bobot volume tanah pada lapisan atas tanah berkaitan erat dengan meningkatnya jumlah serasah, akar, dan kandungan karbon tanah (Carvalho, 2009). Potensi Sekuestrasi Karbon Organik Tanah pada (H. H. Siringoringo) 203 2009). Sementara pasokan bahan organik dari lapisan atas dan laju dekomposisi bahan organik dari bahan akar yang rendah diduga sebagai penyebab BD tanah pada lapisan tanah yang lebih bawah tidak berbeda secara statistik di antara kedua seri waktu pengukuran. Selain itu, perbedaan BD tanah di antara fungsi lahan dapat disebabkan oleh pemadatan akibat penggembalaan ternak dan alat berat, perbedaan volume dan pergantian bahan akar, pengolahan lahan, dan aktivitas biologis (Mendham, 2003). Cadangan karbon dalam tanah meningkat akibat pemberian biochar, 
semakin tinggi takaran biochar yang diberikan semakin tinggi juga cadangan karbon tanah. Penggunaan biochar sekam padi 10 ton/ha menghasilkan cadangan karbon tanah tertinggi yang kemudian diikuti biochar tempurung kelapa dan biochar serbuk gergaji. Penambahan cadangan karbon tanah ini disebabkan karena penambahan bahan organik dalam tanah yang pada gilirannya akan menambah cadangan karbon tanah. Hasil penelitian Setiawan, (2016) bahwa cadangan kabon tanah berbeda-beda tergantung pada keanekaragaman dan kerapatan tumbuhan, tumbuhan dengan kerapatan penutupan yang baik akan menaungi tanah dari radiasi mata hari dan menghindari tanah dari proses pelepasan karbon.

Tinggi-rendahnya simpanan karbon tanah (ton/ha) ditentukan dari tiga variabel utama yang saling terkait (not independent), yaitu konsentrasi karbon organik tanah (SOC) (C\%), bobot volume tanah (BV) (g/cm3 ), karbon organic tanah (SOC). Kehilangan karbon organik tanah lainnya terjadi melalui erosi atau tercuci (leached) ke air tanah (groundwater) atau hilang akibat banjir pada permukaan tanah (IPCC, 2006). Selain itu, sumber pasokan serasah yang berbeda dapat bahkan menghasilkan perubahan komposisi bahan organik tanah (Huang, 2011). Kapasitas tanah berfungsi sebagai penyimpan karbon (carbon sink) juga dipengaruhi oleh berapa cepat serasah merubah C menjadi humus (Kanerva \& Smolander, 2007; Prescott, 2010). Penguraian serasah tidak hanya tergantung pada komposisi kimianya, tetapi juga dipengaruhi oleh kondisi iklim mikro yang ditentukan dengan perkembangan tajuk dan struktur tegakan yang berbeda. Kondisi iklim mikro yang sama mempunyai pengaruh langsung pada tutupan dan tipe tumbuhan bawah, yang selanjutnya mempengaruhi jumlah, komposisi, dan tipe serasah (Berg, 2009). Akar menggabungkan lebih banyak C ke dalam tanah daripada bahan organik yang berada pada lantai hutan (Jones, 2009). Tumbuhan bawah yang didominasi oleh jenis rerumputan akan menggabungkan $\mathrm{C}$ lebih cepat ke dalam bahan organik tanah kerena sistem perakaran berkembang lebih cepat (Andrade, 2008; Laungani \& Knops, 2009).

\section{Sekuestrasi Karbon pada Biomassa Tanaman Kedelai}

Proses penimbunan karbon (C) dalam tubuh tanaman hidup dinamakan proses sekuestrasi (C-sequestration). Dengan demikian mengukur jumlah $\mathrm{C}$ yang disimpan dalam tubuh tanaman hidup (biomasa) pada suatu lahan dapat menggambarkan banyaknya $\mathrm{CO}_{2}$ di atmosfer yang diserap oleh tanaman. Sedangkan pengukuran $C$ yang masih tersimpan dalam bagian tumbuhan yang telah mati (nekromasa) secara tidak langsung menggambarkan CO2 yang tidak dilepaskan ke udara lewat pembakaran.

Tabel 2. Pengaruh Aplikasi Biochar Terhadap Biomassa Pucuk, Biomassa Akar dan Biomassa Total Tanaman

\begin{tabular}{|c|c|c|c|c|c|c|c|c|c|c|c|}
\hline $\mathrm{P}$ & 1 & 2 & 3 & 4 & Rata & 1 & 2 & 3 & 4 & Rata & Total Biomas \\
\hline & \multicolumn{5}{|c|}{ Biomassa Pucuk (ton/ha) } & \multicolumn{5}{|c|}{ Biomassa Akar (ton/ha) } & \\
\hline $\mathrm{b}$ & & & & & & & 1.6 & 1.2 & 1.5 & & 2,75 \\
\hline 0 & 6.73 & 6.16 & 5.77 & 6.29 & 6.24 & 1.31 & 7 & 8 & 2 & 1.44 & \\
\hline $\mathrm{b}$ & & & & & & & 1.8 & 1.9 & 1.6 & & 3,48 \\
\hline 1 & 8.71 & 7.52 & 7.00 & 7.61 & 7.71 & 1.71 & 1 & 2 & 7 & 1.78 & \\
\hline $\mathrm{b}$ & & & & & & & 1.6 & 1.4 & 1.6 & & 2,85 \\
\hline 2 & 9.01 & 6.87 & 7.09 & 8.37 & 7.84 & 1.33 & 4 & 8 & 1 & 1.52 & \\
\hline
\end{tabular}




\begin{tabular}{|c|c|c|c|c|c|c|c|c|c|c|c|}
\hline b & & & & 11.0 & & & 1.5 & 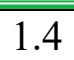 & 1.8 & & 3,33 \\
\hline 3 & 7.17 & 5.48 & 7.15 & 3 & 7.71 & 1.71 & 3 & 3 & 4 & 1.63 & \\
\hline$b$ & 10.4 & 11.4 & 12.2 & 10.1 & 11.0 & & 2.2 & 1.8 & 2.2 & & 4,68 \\
\hline 4 & 8 & 4 & 1 & 9 & 8 & 2.48 & 0 & 8 & 4 & 2.20 & \\
\hline b & 10.7 & & 11.0 & & 10.0 & & 1.5 & 1.8 & 1.7 & & 3,52 \\
\hline 5 & 3 & 9.40 & 1 & 8.88 & 1 & 1.81 & 2 & 0 & 1 & 1.71 & \\
\hline$b$ & 11.3 & & 12.6 & 12.6 & 11.0 & & 1.9 & 1.5 & 1.6 & & 3,22 \\
\hline 6 & 9 & 7.55 & 4 & 4 & 5 & 1.53 & 9 & 5 & 9 & 1.69 & \\
\hline
\end{tabular}

Hasil penelitian menunjukkan bahwa pemberian biochar dari jenis bahan yang berbeda menyebabkan perbedaan biomassa tanaman, demikian juga dengan takaran biochar yang diberikan, semakin tinggi takaran yang diberikan menyebabkan semakin besar juga total biomassa tanaman. Berat biomassa pucuk atau biomassa tanaman bagian atas lebih besar dibandingkan biomassa akar. Tingginya biomassa tanaman kedelai mengindikasikan bahwa tanaman kedelai memiliki tajuk yang tebal dan rapat sehingga menyebabkan penyerapan radiasi matahari lebih banyak.

Tingginya biomassa tanaman dapat mempengaruhi jumlah karbon yang tersimpan dalam tanaman. Biomassa secara langsung dapat menggambarkan kondisi simpanan karbon dalam suatu areal, karena karbon merupakan penguraian $\mathrm{CO} 2$ yang diserap oleh vegetasi hijau yang pada gilirannya menjadi biomassa dan disimpan dalam bentuk karbon.

Tabel 3 . Pengaruh Aplikasi Biochar Terhadap Cadangan Karbon Tanaman Kedelai

\begin{tabular}{lccccc}
\hline Perlakuan & 1 & \multicolumn{5}{c}{2} & 3 & Rata \\
\hline b0 & 223.01 & 234.45 & 202.93 & 194.21 & 213.65 \\
b1 & 436.38 & 341.03 & 327.04 & 355.85 & 365.07 \\
b2 & 385.41 & 301.10 & 281.46 & 349.67 & 329.41 \\
b3 & 312.90 & 223.64 & 306.31 & 529.72 & 343.14 \\
b4 & 611.61 & 639.04 & 660.50 & 623.73 & 633.72 \\
b5 & 582.39 & 478.27 & 578.53 & 446.84 & 521.51 \\
b6 & 626.15 & 396.12 & 687.87 & 659.93 & 592.52 \\
\hline \multicolumn{5}{c}{ Cadangan Karbon Pucuk ton/ha } \\
b0 & 34.74 & 51.08 & 40.04 & 50.59 & 44.11 \\
b1 & 62.16 & 76.58 & 77.05 & 63.97 & 69.94 \\
b2 & 51.23 & 57.07 & 60.62 & 58.98 & 56.98 \\
b3 & 55.55 & 52.93 & 48.09 & 70.97 & 56.89 \\
b4 & 126.13 & 102.96 & 93.32 & 108.04 & 107.61 \\
b5 & 71.57 & 53.32 & 76.19 & 69.63 & 67.68 \\
b6 & 69.66 & 86.54 & 64.62 & 67.11 & 71.98 \\
\hline \multicolumn{5}{c}{ Cadangan Karbon Akar ton/ha } \\
b0 & 257.75 & 285.53 & 242.97 & 244.80 & 257.76 \\
b1 & 498.53 & 417.61 & 404.09 & 419.81 & 435.01 \\
b2 & 436.64 & 358.18 & 342.08 & 408.65 & 386.39 \\
\hline \hline
\end{tabular}




\begin{tabular}{llllll}
\hline \hline b3 & 368.45 & 276.57 & 354.40 & 600.69 & 400.03 \\
b4 & 737.75 & 742.00 & 753.82 & 731.76 & 741.33 \\
b5 & 653.96 & 531.59 & 654.72 & 516.47 & 589.19 \\
b6 & 695.81 & 482.66 & 752.49 & 727.04 & 664.50 \\
\hline
\end{tabular}

Simpanan karbon pada tumbuhan bawah seperti kedelai berbanding lurus dengan biomassanya, nilai simpanan karbon tumbuhan bawah tidak stabil karena keberadaan tumbuhan bawah sangat dinamis sehingga jumlahnya dapat berubah dengan cepat dalam waktu yang singkat (Langi, 2007). Potensi simpanan karbon kedelai pada tanah yang diberi biochar diketahui lebih tinggi dibandingkan pada tanaman kedelai yang dtanam pada tanah tanpa perlakuan tertentu.

Berdasarkan cadangan karbon tanaman yang disajikan pada Tabel 3 diketahui bahwa cadangan karbon tanaman bagian atas lebih tinggi daripada cadangan karbon akar. Sekuestrasi karbon tertinggi ditunjukkan pemberian biochar sekam padi dengan takaran 10 ton/ha, baik pada akar maupun bagian pucuk tanaman. Hairiah dan Rahayu (2007) menyatakan bahwa nilai biomassa dan C-organik akan menentukan besarnya nilai cadangan karbon tersimpan dalam tanaman, karena kuantitas simpanan karbon berbanding lurus dengan kuantitas simpanan biomassa.

Hairiah, (2016) menyatakan bahwa karbon di udara berada dalam bentuk gas yang dinamakan gas asam arang (gas $\mathrm{CO} 2$ ) atau dalam kehidupan sehari-hari gas tersebut dikelompokkan sebagai "gas buang". Karbon di udara bermanfaat bagi tumbuhan yang berdaun hijau untuk melangsungkan proses "fotosinthesis". Selama berfotosinthesis tumbuhan butuh sinar matahari, gas $\mathrm{CO} 2$ yang diserap dari udara, air dan hara yang diserap dari dalam tanah. Sebagai gas buang dari proses fotosintesis dilepaskan O2 (oksigen) yang sangat kita butuhkan untuk bernafas (Gambar 6). Melalui proses fotosintesis, CO2 tersebut diubah menjadi karbohidrat (pati). Pati selanjutnya disebarkan keseluruh tubuh tanaman dan akhirnya ditimbun dalam beberapa organ tanaman seperti daun, batang, ranting, bunga dan buah, kemudian akan gugur sebagai seresah. Secara teknis seresah disebut pula 'sampah kebun', yang selanjutnya akan busuk dan lapuk menjadi bagian dari tanah yang biasanya disebut pula sebagai 'humus'.

Karbon dalam bentuk pati tertimbun dalam tubuh tumbuhan dalam waktu cukup lama tergantung dari jenis tumbuhannya. Untuk jenis tumbuhan tahunan (pohon), umumnya karbon disimpan paling banyak di bagian berkayu selama tanaman tersebut masih hidup. Sedang pada tumbuhan umur pendek, karbon hanya tersimpan dalam waktu singkat saja, setelah tumbuhan mati/panen maka tidak ada lagi penyerap $\mathrm{CO} 2$ di udara, kecuali bila tumbuhan umur pendek hidup berdampingan dengan tumbuhan umur panjang (pohon). Proses penyerapan gas CO2 dari udara dan penimbunan karbon dalam tubuh tanaman hidup dinamakan proses sekuestrasi. Dengan demikian mengukur jumlah karbon yang disimpan dalam tubuh tanaman hidup (biomasa) dalam suatu lahan dapat menggambarkan banyaknya CO2 di atmosfer yang diserap oleh tanaman. Semakin banyak dan semakin lama karbon disimpan dalam tanaman maka sekuestrasi karbon akan semakin besar. Sedangkan jumlah karbon yang hilang dari lahan kita karena panen dan pembakaran dihitung sebagai emisi. Keberadaan pohon besar dalam suatu lahan dapat mempertahankan jumlah karbon yang disimpan, namun demikian keradaan pohon yang berukuran kecil sampai sedang akan membantu menyerap $\mathrm{CO} 2$ di atmosfir dan menjadi 
penyerap karbon dimasa depan. Secara umum fotosintesis mengubah CO2 atmosfer menjadi karbohidrat (plant sugar) yang menyediakan dua rantai makanan: melalui pertumbuhan tunas di atas permukaan tanah dan pertumbuhan akar di bawah permukaan tanah. Ketika tanaman bertumbuh produktif, akar dan keterkaitan fungi/jamur yang menguntungkan dan mikroorganisme lainnya bertumbuh dan meningkatkan SOC. Karbon dalam eksudat akar menyediakan pasokan makanan berharga untuk unsur biota tanah. Pengurai (bakteri, jamur, dan biota yang lebih besar) juga tumbuh dan berkembangbiak, memakan SOC dan mengubahnya menjadi bentuk yang lebih stabil, akhirnya menjadi humus. Aktivitas biota tanah membentuk dan mendaur ulang unsur-unsur hara sementara sebagian karbon dimineralisasi menjadi CO dan hilang ke atmosfer (Liddicoat, 2010). Ketika pasokan dan kehilangan karbon berada dalam keseimbangan satu sama lainnya, tidak ada perubahan bersih pada jumlah SOC. Jika pasokan karbon dari fotosintesis melebihi karbon yang hilang, jumlah SOC bertambah terus-menerus (Onti \& Schulte, 2012). Jika produksi tanaman menurun atau berhenti, pasokan karbon juga menurun atau berhenti. Jika pasokan karbon dari fotosintesis menjadi benar-benar tidak ada, pengurai (bakteri, jamur, dan biota yang lebih besar) hadir untuk mendominasi dan, dengan demikian, kandungan SOC menurun (Liddicoat, 2010).

Pemberian beberapa jenis biochar meningkatkan hasil kedelai dibandingkan tanpa biochar, takaran biochar 5 ton/ha sudah dapat mempengaruhi produksi kedelai. Hasil kedelai (bobot kering biji) tertinggi dijumpai pada perlakuan biochar sekam padi dengan takaran 10 ton/ha, selanjutnya diikuti oleh biochar tempurung kelapa dan biochar serbuk gergaji. Hasil penelitian ini sesuai dengan peneliti-peneliti sebelumnya, Doan, (2015); Githinji (2013); Sun dan Lu (2014); Dariah dan Nurida (2012) bahwa aplikasi biochar ke dalam tanah dapat memperbaiki kualitas tanah dan meningkatkan hasil tanaman.

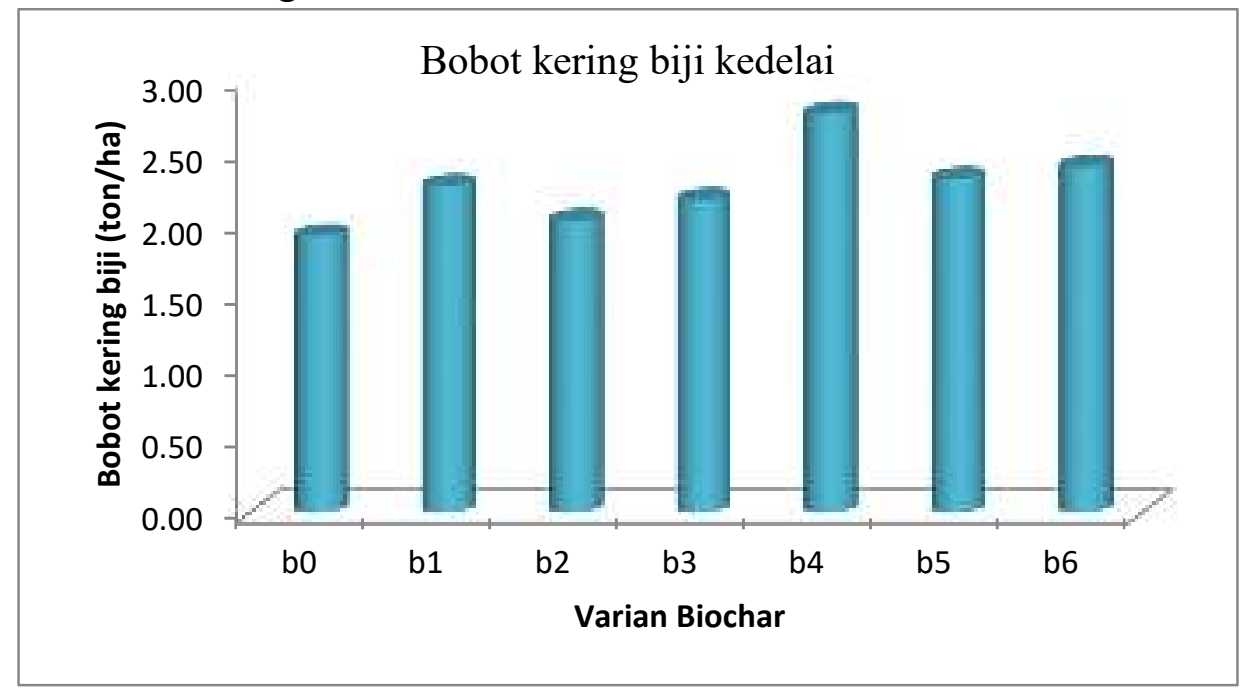

KESIMPULAN DAN SARAN

Berdasarkan hasil penelitian pengembangan soil amandemnt biochar yang telah dilakukan selama satu muim tanam, maka dapat ditarik kesimpulan sbb :

1. Pemberian biochar sekam padi, biochar serbuk gergaji dan biochar tempurung kelapa sudah dapat meningkat kandungan bahan organik, menurunkan bobot volume dan meningkatkan porositas total. 
2. Pemberian biochar sekam padi, biochar serbuk gergaji dan tempurung kelapa meningkatkan biomassa pucuk dan biomassa perakaran tanaman, serta meningkatkan biomassa total.

3. Pemberian biochar sekam padi, serbuk gergaji dan tempurung kelapa menghasilkan cadangan karbon tanah tertinggi. Sekuestrasi karbon tertinggit terjadi pada lahan, dimana cadangan karbon tanaman tertinggi adalah pada bagian puucuk tanaman.

4. Pemberian biochar sekam padi, serbuk gergaji dan tempurung kelapa meningkatkan bobot kering biji kedelai. Hasil kedelai tertinggi dijumpai pada pertanaman uyang diberi biochar sekam padi 10 ton/ha.

\section{UCAPAN TERIMA KASIH}

Terima kasih disampaikan kepada Bapak Rektor Universitas Jambi yang telah mendanai penelitian ini, dan terima kasih kepada Ibu Ketua LPPM yang telah menyetujui pelaksanaan penelitian, terima kasih juga kepada Bapak Dekan Fakultas Pertanian Universitas Jambi yang telah memfasilitasi pelaksanaan penelitian hingga selesai.

\section{DAFTAR PUSTAKA}

Agus F, Wahyunto, Mulyani A, Dariah A, Maswar, Susanti E. 2011. Variasi stock karbon dan emisi CO2 di lahan gambut. Laporan Tengah Tahun KP3I, Balai Besar Litbang Sumberdaya Lahan Pertanian. Bogor. Indonesia (Belum dipublikasi).

Agus F, Subiksa I GM. 2008. Lahan Gambut: Potensi untuk pertanian dan aspek lingkungan. Balai Penelitian Tanah dan World Agroforestry Centre, Bogor. 36p. Agus F, Handayani E, Van Noordwijk M, Idris K, Sabiham S. 2010. Root respiration interferes with peat $\mathrm{CO} 2$ emission measurement. pp. 50-53 In Proceedings 2010 19th World Congress of Soil Science, 1 - 6 August 2010, Brisbane, Australia.

Andrade, H.J., Brook, R., \& Ibrahim, M. (2008). Growth, production and carbon sequestration of silvopastoral systems with native timber species in the dry lowlands of Costa Rica. Plant Soil 308, 11-22

Berg, B., Johansson, M.B., Nilsson, A., Gundersen, P., \& Norell, L. (2009). Sequestration of carbon in the humus layer of Swedish forests-direct measurements. Can. J. For. Res. 39, 962-975.

Carvalho, J.L.N., Cerri, C.E.P., Feigl, B.J., Piccolo, M. de C., Godinho, V.de P., Herpin, U., \& Cerri, C.C. (2009). Conversion of cerrado into agricultural land in the south-westPotensi Sekuestrasi Karbon Organik Tanah pada....(H. H. Siringoringo) 207 ern Amazon: Carbon stocks and soil fertility. Sci. Agric. (Piracicaba, Braz.), 66(2), 233241.

Cline, W, R. 2007. Global Warming and Agriculture: Impact Estimates by Country. Center for Global Development. copublished by the Peterson Institute for International Economics 
Dariah, A., dan N.L. Nurida. 2012. Pemanfaatan Biochar Untuk Meningkatkan Produktivitas Lahan Kering Beriklim Kering. Badan Litbang Pertanian. Bogor. Jurnal Buana Sains 12(1): 33-38.

Dariah, A., S. Sutono., N. L. Nurida., W. Hartatik dan E. Pratiwi. 2015. Pembenah Tanah untuk Meningkatkan Produktivitas Lahan Pertanian. Jurnal Sumberdaya Lahan 9(2): 67-84.

Doan, Thu Thu, Thierry Henry-des-Tureaux , Cornelia Rumpel , Jean-Louis Janeau, Pascal Jouquet, 2015. Impact of compost, vermicompost and biochar on soil fertility, maize yield and soil erosion in Northern Vietnam: A three year mesocosm experiment. Journal Science of the Total Environment 514 (2015) 147-154

Endriani, Sunarti dan Ajidirman. 2013. Pemanfaatan Biochar Cangkang Kelapa Sawit Sebagai Soil Amandement Ultisol Sungai Bahar Jambi. Jurnal Penelitian Universitas Jambi Seri Sains 15(1): 39-46.

Ferizal, M. 2011. Arang Hayati (Biochar) Sebagai Bahan Pembenah Tanah. Balai Pengkajian Teknologi Pertanian Aceh. Edisi Khusus Penas XIII. $2 \mathrm{hlm}$.

Glaser, B., J. Lehman and W. Zech. 2002. Ameliorating Physical and Chemical Properties of Highly Weathered Soils in the Tropics with Charcoals A Review. Biol Fertil Soils. $35: 219-230$.

Hairiah K, Sari RR, Pambudi S, Rahayu S. 2016. Pengukuran cadangan karbon untuk masyarakat. Bahan Ajar 2. Bogor, Indonesia: World Agroforestry Centre (ICRAF) Southeast Asia Regional Program dan Malang, Indonesia: Universitas Brawijaya.

Hairiah K, Rahayu S. 2007. Pengukuran 'cadangan karbon' di berbagai macam penggunaan lahan. Bogor. World Agroforestry Centre - ICRAF SEA Regional Office, and University of Brawijaya, Indonesia. $77 \mathrm{p}$.

Hidayati ,U. 2008. Pemanfaatan Arang Cangkang Kelapa Sawit Untuk Memperbaiki Sifat Fisik Tanah yang Mendukung Pertumbuhan Tanaman Karet. Jurnal Penelitian Karet 26(2): 166-175.

Huang, Z., Davis, M.R., Condron, L.M., \& Clinton, P.W. (2011). Soil carbon pools, plant biomarkers and mean carbon residence time after afforestation of grassland with three tree species. Soil Biol. Biochem. 43, 1341-1349.

IPCC. 2006. Agriculture, forestry and other land use. In S. Eggleston, L. Buendia, K. Miwa, T. Ngara, \& K. Tanabe (Eds.) Guidelines for National Greenhouse Gas Inventories (Vol. 4). IGES, Japan

Jones, D.L., Nguyen, C., \& Finlay, R.D. (2009). Carbon flow in the rhizosphere: carbon trading at the soilroot interface. Plant Soil 321, 5-33

Laungani, R. \& Knops, J.M.H. 2009. The impact of co-occurring tree and grassland species on carbon sequestration and potential biofuel production. GCB Bioenergy 1, 392-403

Lehmann, J., J. Gaunt, and M. Rondon. 2006. Biochar Sequestration in Terrestrial Ecosystems. A review. Mitigation and Adaptation Strategies for Global Change. 11:403-427.

Lehmann, J. 2007. Bioenergy in the Black. Frontiers in Ecology and the Environment. 5(7):381-387. 
Masulili, A. 2010. Rice Husk Biochar for Rice Based Cropping System in Acid Soil 1. The Characteristics of Rice Husk Biochar and its Influence on the Properties of Acid Sulfate Soils and Rice Growth in West Kalimantan, Indonesia. Journal of Agricultural Science 2(1):39-47.

Masulili, A, Suryantini dan A.T.P Irianti. 2014. Pemanfaatan Limbah Padi dan Biomasa Tumbuhan Liar Cromolaena odorata Untuk Meningkatkan Beberapa Sifat Tanah Sulfat Masam Kalimantan Barat. Jurnal Buana Sains 14(2): 7-18.

Nurida, N.L., dan A. Rachman dan Sutono. 2012. Potensi Pembenah Tanah Biochar Dalam Pemulihan Sifat Tanah Terdegradasi dan Peningkatan Hasil Jagung Pada Typic Kanhapludults Lampung. Jurnal Buana Sains 12(1): 69-74.

Nurida, N.L., A. Dariah, dan A. Rachman. 2013. Peningkatan Kualitas Tanah dengan Pembenah Tanah Biochar Limbah Pertanian. Jurnal Tanah dan Iklim. 37(2):69-78.

Onti, T. A. \& Schulte, L. A. (2012). Soil carbon storage. Nature Education Knowledge 3 (10), 35

Prescott, C.E. (2010). Litter decomposition: what controls it and how can we alter it to sequester more carbon in forest soils? Biogeochemistry 101, 1-17

Rona, Y., Widowati dan Sutoyo. 2014. Penggunaan Kompos dan Biochar Untuk Pembibitan Pertumbuhan dan Hasil Cabai Rawit (Capsicum frutenscen L). Fakultas Pertanian. Universitas Tribhuwana Tunggadewi Malang.

Santi, L.P. dan Goenadi, D.H. 2012. Pemanfaatan Biochar Asal Cangkang Kelapa Sawit Sebagai Bahan Pembawa Mikroba Pemantap Agregat. Jurnal Buana Sains 12(1): 7-14.

Sukartono dan W.H Utomo. 2012. Peranan Biochar Sebagai Pembenah Tanah Pada Pertanaman Jagung Di Tanah Lempung Berpasir (Sandy Loam) Semiarid Tropis Lombok Utara. Jurnal Buana Sains 12(1): 91-98.

Suppadit T, Nittaya Phumkokrak, and Pakkapong Poungsuk 2012 The effect of using quail litter biochar on soybean (Glycine max [L.]Merr.) production. Chilean Journal of Agricultural Research 72(2) April-June 2012. Thailand.

Sutono, S., dan N.L. Nurida. 2012. Kemampuan Biochar Memegang Air Pada Tanah Bertekstur Pasir. Jurnal Buana Sains 12(1): 45-52.

Shofiyati R, Las I, Agus F. 2010. Indonesian Soil Data Base and Predicted Stock of Soil Carbon. In Chen Z.S. and F. Agus (eds.) Proceedings of International Workshop on Evaluation and Sustainable Management of Soil Carbon Sequestration in Asian Countries, Bogor, Indonesia, September 28-29, 2010. Pp.73-83 